\title{
Pengaruh Hipertensi Terhadap Tajam Penglihatan
}

\author{
Sudirman $^{1 *}$ \\ Email: sudirman@uniqhba.ac.id \\ ${ }^{1)}$ Dosen Prodi Pendidikan Matematika FKIP UNIQHBA
}

\begin{abstract}
ABSTRAK
Penurunan tajam penglihatan selain dipengaruhi oleh katarak juga disebabkan oleh penyakit yang mempengaruhi retina. Hipertensi adalah penyakit yang mempengaruhi retina. Penduduk di wilayah Puskesmas Kopang memiliki keadaan sosial ekonomi dan tingkat pendidikan yang masih rendah. Penelitian ini bertujuan untuk mengetahui pengaruh hipertensi terhadap tajam penglihatan. Penelitian ini dilakukan di Puskesmas Kopang, Lombok Tengah mulai April sampai Mei 2018. Rancangan penelitian adalah cross sectional dengan jumlah sampel 73 responden yang berumur 40 tahun keatas yang diambil secara simple random sampling. Pengukuran tajam penglihatan menggunakan Tumbling E, pengukuran hipertensi $(\geq 140 / 90 \mathrm{mmHg})$ ditentukan dengan Automatic Blood Pressure dan untuk mengetahui signifikasi data di analisis menggunakan uji Mann - Whitney menggunakan program SPSS versi 16.0 dengan tingkat kepercayaan 95\% $(\alpha=0.05)$. Berdasarkan hasil analisis statistik, hipertensi berpengaruh secara signifikan $(0.00<0.05)$ terhadap tajam penglihatan yaitu sebesar $47.9 \%$, artinya hipertensi menyebabkan terjadinya penurunan tajam penglihatan sebesar $47.9 \%$.
\end{abstract}

Kata kunci: Hipertensi, Tajam Penglihatan

\begin{abstract}
The aim of this study was to evaluate the influence of hypertension to visual acuity. This study is non experimental with cross-sectional method and was carried out involving 73 respondents as sample from a population of 244 people aged 40 years, who were taken by simple random sampling in Kopang Primary Health Care, Central Lombok. Statistical analysis shows, this study revealed that the hypertension was significantly $(\mathrm{P}<0.05)$ influenced to visual acuity was equal to $47.9 \%$, it mean that hypertension was found in $47.9 \%$ of those with low vision.
\end{abstract}

Keywords: Hypertension, Visual Acuity

\section{A. LATAR BELAKANG}

Pemeriksaan tajam penglihatan merupakan pemeriksaan fungsi mata. Gangguan penglihatan memerlukan pemeriksaan untuk mengetahui sebab kelainan mata yang mengakibatkan turunnya tajam penglihatan. Untuk mengetahui tajam penglihatan seseorang dapat dilakukan pengukuran dengan menggunakan kartu Snellen (Snellen Chart) atau tumbling E [1]. Penyebab tersering turunnya tajam penglihatan adalah katarak, parut kornea yang mempengaruhi jalur penglihatan dan penyakitpenyakit yang mempengaruhi retina [2]. Degenarasi makular, diabetes [2] dan hipertensi [3] adalah penyakit yang bisa mempengaruhi retina. Pekerjaan yang banyak terpapar sinar matahari mengakibatkan terkena sinar ultraviolet [4], sinar ultraviolet diperkirakan mempengaruhi ketajaman penglihatan.
Diabetes Mellitus (DM) adalah salah satu penyakit yang diperkirakan mempercepat proses turunnya tajam penglihatan, karena DM dapat mempengaruhi kejernihan lensa akibat peningkatan kadar gula darah dalam lensa [5]. Selain pada lensa, diabetes mellitus juga dapat menimbulkan komplikasi pada retina yang disebut retinopati diabetik, retinopati diabetik mengakibatkan terjadi kerusakan pembuluh darah retina atau lapisan saraf mata sehingga mengalami kebocoran. Akibatnya, terjadi penumpukan cairan (eksudat) yang mengandung lemak serta pendarahan pada retina [6].

Selain diabetes, hipertensi diperkirakan menjadi salah satu penyebab turunnya tajam penglihatan. Hipertensi atau darah tinggi dialami hampir sebagian besar penderita diabetes, hipertensi 
merupakan salah satu komplikasi dari diabetes, diperkirakan muncul menyertai komplikasi lainnya yaitu turunnya tajam penglihatan. Retina merupakan bagian tubuh yang secara langsung bisa menunjukkan adanya efek dari hipertensi terhadap arteriola (pembuluh darah kecil).

Topografi wilayah Puskesmas Kopang terdiri dari, lereng/bukit, dan dataran, mayoritas pekejaannya sebagai petani $(42.79 \%)$, persentase penduduk miskin (pra sejahtera) sebesar $37.41 \%$ dan $41.83 \%$ penduduknya belum pernah sekolah atau tidak tamat Sekolah Dasar (SD) [7] dan prevalensi katarak di Lombok sebesar 11.6\% [8]. Data diatas menggambarkan bahwa penduduk disekitar Puskesmas Kopang memiliki keadaan sosial ekonomi dan tingkat pendidikan yang masih rendah, hal inilah yang menyebabkan kurangnya akses informasi dan pengetahuan kesehatan pada masyarakat, sehingga akan menimbulkan ketidakberdayaan dan ketidaktahuan masyarakat tentang kesehatan mata.

Puskesmas Kopang merupakan salah satu dari 2 (dua) puskesmas yang ditunjuk oleh pemerintah pusat dan daerah melalui Dinas Kesehatan NTB yang bekerjasama dengan Helen Keller Internasional untuk dijadikan proyek percontohan diselenggarakannya kegiatan operasi mata sejak tahun 2005. Pada tahun 2008 dari 1739 pasien yang memeriksakan diri di Puskesmas Kopang, 1464 orang dinyatakan positif menderita katarak, sebanyak $35.60 \%$ ditunda operasinya karena menderita diabetes dan $31.81 \%$ karena hipertensi. Hal ini berarti, tingginya angka kejadian katarak diatas diduga disebabkan oleh penyakit diabetes mellitus dan hipertensi.

Berdasarkan uraian diatas, penurunan tajam penglihatan selain dipengaruhi oleh katarak juga disebabkan oleh penyakit yang mempengaruhi retina, hipertensi adalah penyakit yang mempengaruhi retina. Tujuan dari penenilitian ini adalah untuk mengetahui pengaruh hipertensi terhadap tajam penglihatan di Puskesmas Kopang. Hasil penelitian ini diharapkan Bagi masyarakat, dapat memberikan sumbangan pengetahuan, sehingga dapat dimanfaatkan dalam upaya pencegahan penurunan tajam penglihatan sedini mungkin di masyarakat.

\section{B. METODE PENELITIAN}

\section{Rancangan Penelitian}

Rancangan penelitian ini adalah penelitian potong lintang (cross sectional) dengan sistem simple random sampling single proportion.

\section{Populasi dan Sampel Penelitian}

Populasi penelitian ini adalah seluruh pasien yang melakukan pemeriksaan mata di Puskesmas Kopang Lombok Tengah pada tahun 2017, yakni sebesar 343 orang dengan jumlah sampel 73 responden yang berumur 40 tahun keatas.

\section{Tempat dan Waktu Penelitian}

Penelitian ini dilakukan di Puskesmas Kopang, Kabupaten Lombok Tengah dan berlangsung dari bulan April 2018 sampai Mei 2018.

\section{Tehnik pengumpulan data}

Mencatat identitas subyek penelitian, meliputi nama, alamat dan usia serta dilakukan pengisian formulir penelitian secara lengkap sesuai alur penelitian yang telah ditentukan.

Meminta responden untuk menutupi bagian mata kirinya (Ocular Sinistra) dengan menggunakan telapak tangan kirinya tetapi jangan ditekan. Memposisikan telapak tangan responden seolah-olah memegang telur dalam genggamannya kemudian tekapkan ke bagian mata yang akan di tes terlebih dahulu.

Menggunakan tali untuk mengukur 6 meter yang memiliki simpul dibagian tengah (jarak 3 meter) kemudian mempersilahkan responden untuk duduk atau berdiri dengan jarak 6 meter berhadapan dari tempat petugas lapangan. Posisi responden yang duduk atau berdiri harus membelakangi matahari atau cahaya (tidak menyilaukan mata responden).

Menjelaskan bahwa responden harus menunjukkan arah sesuai dengan arah simbol E tersebut (ke atas, ke bawah, ke kiri atau ke kanan). Tumbling E ini dibuat selain untuk orang yang bisa membaca juga untuk orang yang tidak bisa membaca, karena cukup memberitahu arah kaki dari huruf $\mathrm{E}$ tersebut 
Responden dikatakan bisa menjawab dengan benar jika responden sanggup menjawab 4 pertanyaan dengan benar secara berturut-turut atau jika responden sanggup menjawab 5 dari 6 pertanyaan dengan benar, atau jika responden sanggup menjawab 6 dari 8 pertanyaan dengan benar [9]

Jika responden bisa menjawab benar pada jarak 6 meter dengan ukuran tumbling $\mathrm{E}$ kecil (18) maka ukuran visus (ketajaman penglihatan) responden adalah 6/18. Tetapi apabila tidak memenuhi kriteria benar diatas dilanjutkan dengan pengukuran visus $6 / 60$.

Jika responden bisa menjawab benar pada jarak 6 meter dengan ukuran tumbling $\mathrm{E}$ besar (60) maka ukuran visus (ketajaman penglihatan) responden adalah $6 / 60$, tetapi Jika responden tidak dapat melihat huruf E besar (60) dari jarak 6 meter, maka peneliti harus maju ke jarak 3 meter dan melakukan tes ketajaman penglihatan dengan huruf $\mathrm{E}$ besar (60).

Jika responden bisa menjawab benar pada jarak 3 meter dengan ukuran tumbling $\mathrm{E}$ besar (60) maka ukuran visus (ketajaman penglihatan) responden adalah $3 / 60$, tetapi Jika responden tidak dapat melihat huruf $\mathrm{E}$ besar (60) dari jarak 3 meter, maka peneliti harus maju ke jarak 1 meter dan melakukan tes ketajaman penglihatan dengan huruf $\mathrm{E}$ besar (60) atau melakukan tes menghitung jari.

Jika responden bisa menjawab benar pada jarak 1 meter dengan ukuran tumbling $\mathrm{E}$ besar (60) atau bisa menjawab benar dengan menghitung jari maka ukuran visus (ketajaman penglihatan) responden adalah $1 / 60$, tetapi Jika responden tidak dapat melihat huruf $\mathrm{E}$ besar (60) atau menghitung jari dari jarak 1 meter, maka peneliti harus melakukan tes persepsi cahaya untuk mengetahui reaksi pupil responden dengan menggunakan senter, caranya dengan mengarahkan cahaya senter dari atas, bawah, kiri dan kanan.

Jika responden bisa menjawab benar arah senter setelah dilakukan tes reaksi pupil, maka ukuran visus responden adalah PL(+) (Positif Perception Light). Tetapi apabila tidak bisa menjawab benar arah senter setelah dilakukan tes reaksi pupil, maka ukuran visus responen adalah PL (-) (Negatif Perception Light). Biasanya kalau ukuran visus responden PL (-) diperkirakan sarafnya sudah rusak, sehingga sulit disembuhkan.

Bila pengukuran visus untuk melihat reaksi pupil sudah selesai maka dilanjutkan pengukuran visus untuk mata kanan (Ocular Dextra).

Jika ditemukan visus kurang dari 6/18 maka responden tersebut diperkirakan mengalami penurunan ketajaman penglihatan.

Setelah pengukuran visus selesai, selanjutnya dilakukan tes laboratorium untuk memeriksa glukosa darah dan Tekanan darah. Tekanan darah diukur pada posisi duduk sebanyak tiga kali pengukuran pada rentang 10 menit.

\section{Analisa Data}

Hasil penelitian diuji dengan Mann Whitney test yang merupakan uji alternatif dari uji $\mathrm{t}$ - test independent jika distribusi data tidak normal. Pengolahan dan analisa data menggunakan bantuan program SPSS versi 16.0 dengan tingkat kepercayaan $95 \%(\alpha=0.05)$.

\section{Alur Penelitian}

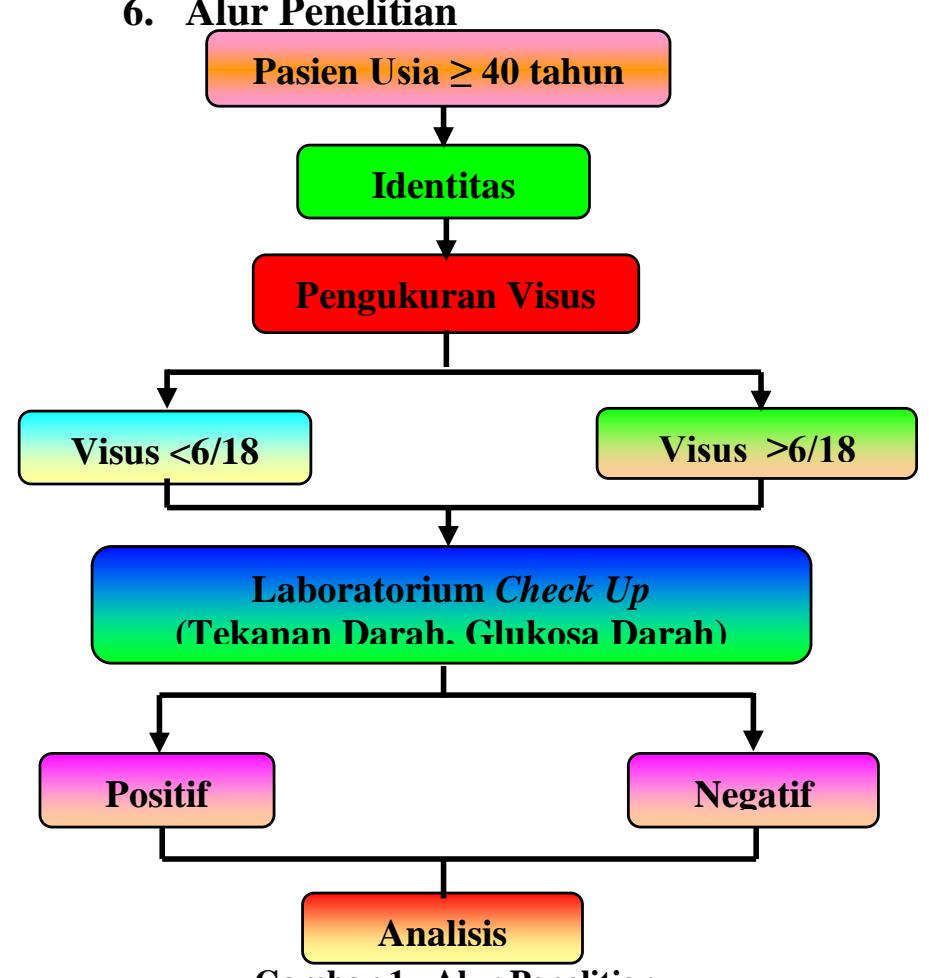

Gambar 1. Alur Penelitian 


\section{HASIL DAN PEMBAHASAN \\ Pengaruh Tekanan Darah Terhadap Tajam penglihatan}

Pengaruh antara hipertensi dengan tajam penglihatan berdasarkan hasil analisis statistik ternyata berpengaruh secara signifikan $(\mathrm{p}<0.05)$, dengan Odd Ratio (OR ) $=6.364$ dan Confidence Interval $(\mathrm{CI})=2.230-18.157$, artinya responden yang mengalami hipertensi kemungkinan besar akan mengalami resiko terjadinya penurunan tajam penglihatan (low vision). Dalam penelitian ini ditemukan, responden yang menderita hipertensi besar kemungkinannya mengalami penurunan tajam penglihatan sebesar 47.9\% (Gambar 2).

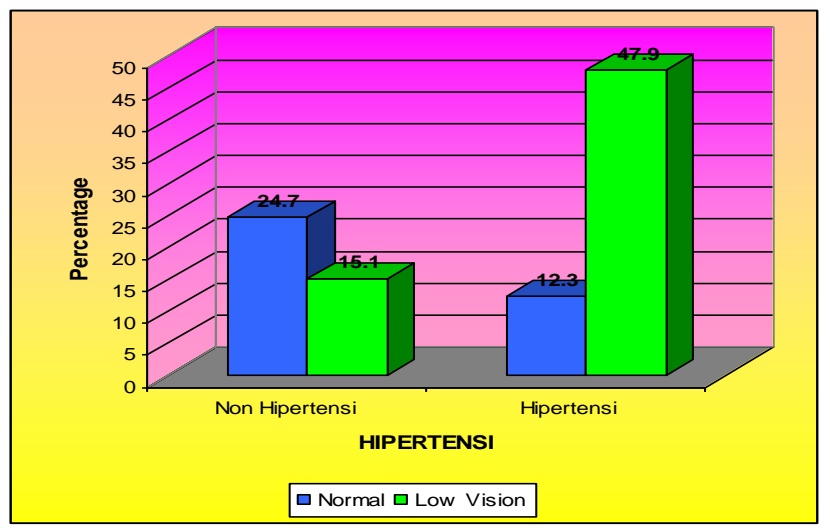

Gambar 2. Grafik Hipertensi Dengan Tajam Penglihatan

Flamingham eye study menemukan ada hubungan antara tekanan darah sistol dengan katarak [10]. Sementara Clayton, et.al., (1980) melaporkan ada pengaruh secara signifikan antara tekanan darah diastol dengan katarak. Barbados eye study menambahkan tekanan darah diastol lebih dari 95 mmhg meningkatkan terjadinya kekeruhan lensa pada katarak [11]. Chen et.al.,(1988) melakukan penelitian case control (studi kasus) menemukan bahwa responden yang berumur kurang dari 67 tahun berpengaruh positif terjadinya katarak akibat hipertensi [12]. Shakil, et.al., (2008) melakukan penelitian di Karachi pada 160 responden laki - laki yang berumur 40 tahun keatas pada katarak senilis, dari hasil penelitiannya menemukan bahwa tekanan darah sistol berpengaruh terhadap katarak senile $(\mathrm{P}<0.001)$, tekanan darah diastol juga berpengaruh terhadap katarak senilis $(\mathrm{P}<0.001)$ [13]. Hipertensi paling sering menyerang golongan usia diatas 40 tahun, menurut data tahun 1989, di Amerika Serikat, $40 \%$ penduduk usia diatas 40 tahun dan $70 \%$ usia diatas 60 tahun menderita hipertensi [14].

Penelitian dilakukan oleh Bener, et.al., (2006) pada umur 50 tahun keatas di Doha Qatar dengan 96.348 responden ditemukan bahwa hipertensi beresiko mengalami low vision $(\mathrm{OR}=1.30 ; \mathrm{CI}=1.11$ 1.52) [15]. Hipertensi secara signifikan berpengaruh terhadap turunnya tajam penglihatan (low vision). Analisis lanjut dengan regresi logistic menunjukkan bahwa low vision disebabkan menderita hipertensi [16].

Hipertensi bisa menyebabkan penurunan tajam penglihatan (visus), hal ini terjadi karena dengan tekanan darah tinggi akan menyebabkan tekanan bola mata akan meningkat, didalam bola mata terdapat lapisan sel yang memproduksi cairan yang disebut akuos humor. Cairan ini akan mengalir ke dalam bola mata kemudian keluar dari bola mata melalui saluran kecil menuju pembuluh darah. Jika saluran ini terhambat atau mengecil maka produksi cairan akan meningkat, akibatnya tekanan didalam bola mata akan meninggi dan merusak serabut saraf mata. Apabila tidak segera ditangani kerusakan yang terjadi pada saraf mata ini akan dapat menimbulkan kebutaan yang bersifat permanen atau tidak dapat disembuhkan lagi. Jadi penurunan tajam penglihatan karena retinopati hipertensif biasanya disebabkan oleh makulopati edema, dan bisa disebabkan karena regangan yang cukup hebat dari serabut-serabut saraf nervus optikus [12].

\section{KESIMPULAN}

Berdasarkan hasil dan pembahasan dapat disimpulkan bahwa hipertensi, interaksi diabetes mellitus dan hipertensi serta pekerjaan berpengaruh secara signifikan terhadap tajam penglihatan yaitu sebesar $47.9 \%$.

\section{DAFTAR PUSTAKA}

[1] Fitriani, D.G., 2009. Tingkat Kepuasan Pasien Setelah Operasi Katarak Dengan Metode SICS di Lombok. Tesis. Program Studi Ilmu 
Penyakit Mata, Fakultas Kedokteran, Universitas Indonesia. Jakarta.

[2] Guyton AC, Hall JE., 1996. Mata I. Sifat Optik Mata. Dalam: Guyton AC, penyunting. Buku Ajar Fisiologi Kedokteran edisi 9. Jakarta; Penerbit buku Kedokteran EGC; 779.

[3] Ocampo V, 2008. Cataract, Senile. (Online) Available on: http://www.emedicine.com/oph/. [Accessed: 2009 December 25].

[4] Ziahulhak, S.R., 2007. Asosiasi katarak dan Pterygium di Kalimantan Timur. Tesis. Program Studi Ilmu Penyakit Mata, Fakultas Kedokteran, Universitas Indonesia. Jakarta.

[5] Rosenfeld S, and Blecher, MH. 2006d. Pathology; Cataracts, Metabolic Cataracts. In: Rosenfeld S, editors. Lens \& Cataract. 20062007. San Fransisco; American Assosciation of Ophtalmology; 2006.

[6] Antonetti1 DA, Alistair JB, Sarah KB, Willard MF, Thomas WG, Leonard SJ, Mark K, Scot RK, Kyle K, Kathryn FL, Christopher CN, Patrick GQ, Lakshman S, Ian AS., 2006. Retinopaty Diabetic. (Online) (http://kireihimee.blogspot.com/retinopatidiabetes-jurnal.html). Diakses: 25 Januari 2010.

[7] BPS, 2008. Badan Pusat Statistik Kecamatan Dalam Angka Dalam Angka. Mataram.

[8] Agustiawan R. 2006. Prevalensi katarak senilis dan hubungannya dengan indeks massa tubuh di pulau Lombok. Tesis. Program Studi Ilmu Penyakit Mata, Fakultas Kedokteran, Universtias Indonesia. Jakarta.

[9] Limburg H., 2004. Manual for Rapid Assessment of Cataract Surgical Services. WHO Prevention of blindness and deafness; Switzerland.

[10] Kahn, HA., Leibowitz, HM., Ganley, JP., 1977. The Framingham Eye Study. Association of Ophtalmic Pathology with sigle variable previously measured in the Framingham Heart Study. Am J Epidemiol, 106:33-41.

[11] Clyton, R.M., Cuthbert, J., Philips, C.I., 1980. Analysisi of Individual Cataract Patient and their Lenses a progress report. Exp Eye Res; 31:553.

[12] Chen, TT., Hockwin, O., Dobbs, R., 1988. Cataract and Health Status: a case - control study. Ophthal Res 20: $1-9$.

[13] Shakil, M., Ahmed, S.T., Samiullah, S., Perveen, K., 2008. Influence of Hypertention and Diabetes Mellitus on Senile Cataract. Karachi, Pakistan. Pak J Physiol : 4 (2)

[14] Papente, D., 2009a. Retinopati Hipertensif. (Online) (http://dianpapente.blogspot.com). Accessed : 20 Januari 2010

[15]Bener, A., Huda S. A., Fareed A. W., Sara M. D., 2006. Risk Factors for Low Vision in Elderly People in a Rapidly Developed Society. Asian J Ophthalmol. 10:126-129., (Online) (www.seagig.org). Accessed, 22 January 2010

[16] Idil, A., Caliskan, D., Ocaktan, E., 2004. The prevalence of blindness and low vision in older onset diabetes mellitus and associated faktors: A community-based study. European Journal of Ophthalmology. 2004, vol. 14, no4, pp. 298. (Online). (http://cat.inist.fr/?aModele=afficheN\&cpsidt =16212162). Accessed : 20 Januari 2010 